\title{
The Use of Signs and the Coding of Prefix Markers by Teachers at a School for the Deaf
}

\author{
Myrtle L Aron, Ph D (Witwatersrand) \\ Robyn E Lewis, BA(Log.) (Witwatersrand) BA Soc.Science (UNISA) \\ Judy L Willemse, BA (Sp. \& H Therapy) (Witwatersrand) \\ Department of Speech Pathology and Audiology \\ University of the Witwatersrand, Johannesburg
}

\begin{abstract}
The use of aspects of an artificially devised manual code in a black school for the deaf was examined. The encoding of prefixes, bound with the noun class system, in Tswana as used by seven teachers was studied as well as the consistency of the teachers to code lexical items. Results indicated the absence of signed prefix markers, inconsistency in signing lexical items and much variability among teachers in the signs used. The educational and research implications are discussed.

\section{OPSOMMING}

Die gebruik van aspekte van 'n kunsmatig ontwikkelde gebarestelsel in 'n swart skool vir dowes, is ondersoek. Die enkodering van voorvoegsels verbonde aan die naamwoordklasstelsel in Tswana soos gebruik deur sewe onderwysers is bestudeer, asook die konstantheid. van die onderwyser se vermoë om leksikale items te kodeer. Resultate dui op die afwesigheid van voorvoegselgebare, onkonstantheid van leksikale gebare en baie variasie onder onderwysers t.o.v. die gebare wat hulle gebruik. Die opvoedkundige en navorsingsimplikasies word. bespreek.
\end{abstract}

(C) SASHA 1986 
The objective of deaf education has always been to teach the child the language of his culture - the culture of the hearing society in which he must live (Bornstein, 1978; Lewis 1984). This objective has pertained irrespective of the mode of communication used in in teaching deaf children. The long standing conflict between the use of oralism and manual communication still prevails although there has been a shift over the last twenty years in most education institutions for the deaf towards the use of manual communication often within a total communication framework. This shift has come about largely due to the apparent failure of oralism and oral education to teach spoken language and the increased use, interest and research into sign languages.

Total Communication embraces an eclectic philosophy, which includes the combined use of a sign language system, manual coding, fingerspelling, speech, auditory training, speech reading, amplification, cueing and any other means whereby the child is taught to encode and decode language. A true natural sign language, which is the visual-gestural language of a deaf community, has its own lexicon, "phonological" and syntactic structure which is systematic and rule-governed. Its basic encoding unit is the word represented by a sign. Inflectional marking is distinguished by spatial temporal dimensions. Nonmanual signs, such as stylised facial expression, also denote syntactic forms, such as question-type and subordinate clauses. (Klima \& Belugi 1980; Liddell, 1980; Stokoe, 1978).

It is expected that existing "natural" sign languages in South Africa would show great divergence from each other due to the diverse ethnic, demographic and politically induced separation of social groups as well as differences in the spoken mother tongues. Natural sign language plays a central role in maintaining the culture and ethnocentricity of deaf communities and is bound to the whole culture on one hand and physical constraints of the users on the other (Stokoe 1978; Cokeley and Baker 1980; Erting 1981).

Manual coding differs from natural sign in that it has been artifically devised by educationalists to represent the syntax of spoken language. In addition, some codes represent the morphological structure of the language in varying degrees (Crystal et al. 1976; Evans 1982). However, it is important to note that the more reputable and widely used of these codes supplement the natural sign language, rather than replacing it. In order to relate sign language to coding, Woodward (1972) suggested a sign continuum, with natural sign language at one end and the contrived sign systems at the other. A pidgin sign language occurs between the two extremes and incorporates elements of both signing and coding - it derives from the necessity for communication between deaf and hearing individuals. Manual codes (MC) are used in educational settings and never as the home language of deaf people. Examples of MCs include:- Signed English, Manual English, Seeing Essential English (SEE) and Signing Exact English (SEE2), the Rochester Fingerspelling Method and the Paget-Gorman Sign System (PG). The latter system was developed in England and is of significance in South Africa. It was first introduced at the Kutlwanong School for the Deaf in Bophuthatswana some twenty-five years ago. No doubt it changed its form over the years of usage and undoubtedly provided part of the framework for the text Talking to the Deaf developed by Nieder-Heitmann past principal of Kutlwanong school for some years. This text has now been introduced into all black schools for the deaf in Southern Africa. Teaching staff are trained to use Talking to the Deaf by means of short courses and videotape (Van der Merwe, 1986).

The book Talking to the Deaf consists of 1500 signs which are claimed to be representative of signs used by the majority of deaf
South Africans. There is no empirical evidence or published data to support this claim. Penn et al. (1984) provide preliminary evidence to show that these signs are not used by all deaf groups. The relationship of the Nieder-Heitmann $(\mathrm{N}-\mathrm{H})$ signs to natural sign languages is therefore much in question.

The South African black languages are heavily morphological, being characterised by a noun class system and extensive agreement based upon that system. Prefixes on the noun stem indicate noun class and number. The prefix determines the form of the agreement morphemes of the other sentence constituents, all of which must be brought into agreement with the determining head noun (Cole, 1982). Although the $\mathrm{N}-\mathrm{H}$ code makes some provisions for manually coding the syntax of black languages, this does not extend to the noun class system. According to Gustason (1983) an effective code increases the input of morphological markers, word endings and other structural elements.

It appears relevant and necessary to explore whether the use by teachers of the recently introduced dictionary of signs - Talking to the Deaf (Nieder-Heitmann, 1980) incorporates adaptations such as prefix markers intrinsic to Tswana, the spoken language of the area. One black school for the deaf was selected for studying this.

\section{METHOD}

Aims of this study

(1) To determine whether the teachers in a black school for the deaf are encoding certain prefixes of the Tswana language, and if so, what form of coding they are using.

(2) To examine the consistency with which the teachers are reproducing there prefix markers.

(3) To ascertain whether the sign for a lexical item (noun) remains the same when used in isolation and in context by each Teacher Subject.

(4) To note whether there is any influence of the signs from the original Paget-Gorman system on the signs used by the subjects for lexical items.

Seven subjects (A,B,C,D,E,F \& G), all teachers at a black school for the deaf were selected. In addition, twenty-one pupils at the school were used to simulate a communicative interaction between teacher and pupil. The Teacher Subjects (TS's) were required to be native Tswana speakers and to have taught at the school for at least two years so as to be familiar with the signing methods in use. All the TS's were teaching standards $1-5$, in order to ensure that a sign system was used in the classroom, and that the test items were appropriate and meaningful.

The pupils used to simulate a classroom situation were congenitally deaf, their home language was Tswana and they had attended the school for a minimum of two years. They were therefore familiar with the signing system used during this time period.

A National WV361 portable videocamera was used to record each TS's performance on the tasks.

Five Tswana nouns, each from a different noun class and in singular and plural forms were selected. These nouns appear in Talking to the Deaf (Nieder-Heitmann 1980). The nouns selected were:

Noun Class

Noun Class 2

Noun Class 3

Noun Class 4

Noun Class 5

$\begin{array}{ll}\text { moruti } & \text { (teacher) } \\ \text { mollo } & \text { (five) } \\ \text { leru } & \text { (cloud) } \\ \text { segokgo } & \text { (spider) } \\ \text { podi } & \text { (goat) }\end{array}$


These lexical items were chosen for their frequency of use and relevance within the teaching situation. Due to time limitations Noun Classes la, 6, 7, 8 and 9 were excluded. Classes I to 4 take both singular and plural prefixes. Multi-syllabic words in class 5 do not take a singular prefix (Cole, 1982). This class was included to ascertain whether coding of the singular occurs in spite of the absence of a prefix. As the plural prefixes of class 4 and 5 nouns are the same, it would be of interest to note whether they were coded differently.

In addition, the object pronouns of each class were included in the test material as their grammatical form corresponds to the noun prefix.

The object pronouns are as follows:-

$\begin{array}{lll}\text { Noun Class 1 } & \text { Ke a mo rata } & \text { (I like him/her) } \\ \text { Noun Class 2 } & \text { Ke a o besa } & \text { (I light it) } \\ \text { Noun Class 3 } & \text { Ke a le bona } & \text { (I see it) } \\ \text { Noun Class 4 } & \text { Ke a se bolaya } & \text { (I kill it) } \\ \text { Noun Class 5 } & \text { Ke a e gama } & \text { (I milk it) }\end{array}$

Each TS was required to sign the selected nouns in the following forms:

(I) Singular - in isolation: moruti (teacher).

(2) Singular - in context: Ke rata moruti (I like the teacher).

(3) Singular pronoun: Ke a mo rata (I like him/her).

(4) Plural in isolation: baruti (teachers)

(5) Plural in context: Ke rate baruti (I like the teachers).

(6) Plural pronoun: Ke a ba rata (I like them).

The subjects were video recorded signing the five nouns to the examiner (E) alone, and to three pupils. This was to ascertain whether the TS's would convey the prefix markers in an instructional setting with more deliberation. The nouns were signed in isolation and in context to see if they changed in form with varied syntactic contexts.

At the end of the study the TS's were also required to complete a questionnaire concerning their awareness of the noun class system in Tswana, and their need to convey such information to their pupils. In addition, information which might influence the TS's proficiency in sign usage was tapped, namely: teaching qualifications, length of teaching experience at the school, method of sign instruction, and perception of consistency of sign usage at the school.

A questionnaire was also completed by the school principal, concerning the school's policy to signing, how the noun class system should be taught and the instruction of teachers in the system.

\section{ANALYSIS OF DATA}

The signed nouns will be described, using the Nieder-Heitmann $(\mathrm{N}-\mathrm{H})$ code as reference. In addition, the Paget-Gorman signs will be considered in order to compare this original code with $\mathrm{N}-\mathrm{H}$ and the TS's variations of the $\mathrm{N}-\mathrm{H}$ code. Each signed noun produced by the TS's was recorded as the same as the N-H system, or a variation (V) or as a totally different sign (D) to the $\mathrm{N}-\mathrm{H}$ system. The variations or the different signs from the $\mathrm{N}-\mathrm{H}$ were arranged in terms of the three cheremes described by Stokoe (1976):

a) DEZ (Designator) - the configuration of the hands,

b) TAB (Tabula) - the location on or near the body while the sign is made,

(c) SIG (Signation) - the movement aspect of the hands.

In addition, the signed noun in isolation (condition "a") was compared to its use in a syntactic context (condition "b") and described as the same (S) or different (D).
Two graduate speech therapists acted as raters to analyse a video sample of the teachers' signs to assess the accuracy of the analysis and categorization of all the signs as determined by one of the
authors.

\section{RESULTS}

I. Signed Nouns

A. Description of signs

Table 1 provides a description of the responses recorded and denotes whether the signs used were the same as described by Nieder-Heitmann (1980), or a variation thereof - the variations used are described in the table. Table 2 provides a summary of the data in Table 1 and indicates the percentage scores of whether the responses were Nieder-Heitmann signs, variations thereof or totally different signs.

It can be seen from both Table 1 and Table 2 that consistency in signing between the TS's is minimal. Only for the nouns "moruti" and "mollo" is there some overlap, where two TS's used the same variation. Other variations are used exclusively by each TS, however, many of the variations are minimal, differing in a single chereme. It can be noted from Table 2 that a large percentage of signed nouns used are variations of the $\mathrm{N}-\mathrm{H}$ signs (X80\%).

There was one occurrence of "moruti" which was totally different, and four occurrences for "podi". It is interesting to notc that all TS's used the sign "preacher" rather than "teacher" (moruti). Stokoe and Kuschell (1979) note the significance of cultural factors in language and this may be an example of such cultural factors.

Comparing Tables 1 and 3 it is clearly evident that the $P-G$ signs differ extensively from both $\mathrm{N}-\mathrm{H}$ and the TS's variations. Reference will be made in the discussion, to the significance of the lack of similarity between the P-G and the teacher variations, although a study of the pupil's use of natural sign as compared with P-G would be of significant interest.

B. Consistency of use in isolation as compared to use in context There were two occurrences out of a total of seventy in which the signed nouns were different when used in isolation and context. The influence of syntactic context did not appear to affect the formation of the sign. However, as only a single syntactic context was used, this finding must be viewed with caution. Writers such as Stokoe (1976), and Klima and Bellugi (1980) have illustrated much variance in signing in context. Signs may vary in terms of spatial and temporal dimensions.

C. Consistency of use in the demonstration of signs by the TS's to the $\mathrm{E}$ as compared to the use of signs to pupils.

There was also high consistency $(80 \%)$ for the two situations. Native users of sign language belong to a diglossic community, implying varieties of signing used by the same speaker under different conditions, particularly when addressing deaf or hearing individuals. As the TS's are not native users of sign, and only use it in the educational setting, this may explain the non-variance.

\section{Prefix Markers}

Signed prefix markers were not used by the TS's for any of the test items. This finding indicates that no manual means exist in the signing system for coding the variety of noun classes in Tswana. This was substantiated by the TS's answers to the questionnaire. Five TS's reported that the noun class system is not taught formally, but is deduced by the pupils from the written form. This written form is recorded on a wall-chart, used for leaming drills. The school principal was uncertain as to how the noun prefixes 
Table 1 Description of the variations with DEZ, TAB and SIG formations of the lexical items used by the Teacher Subjects as compared to

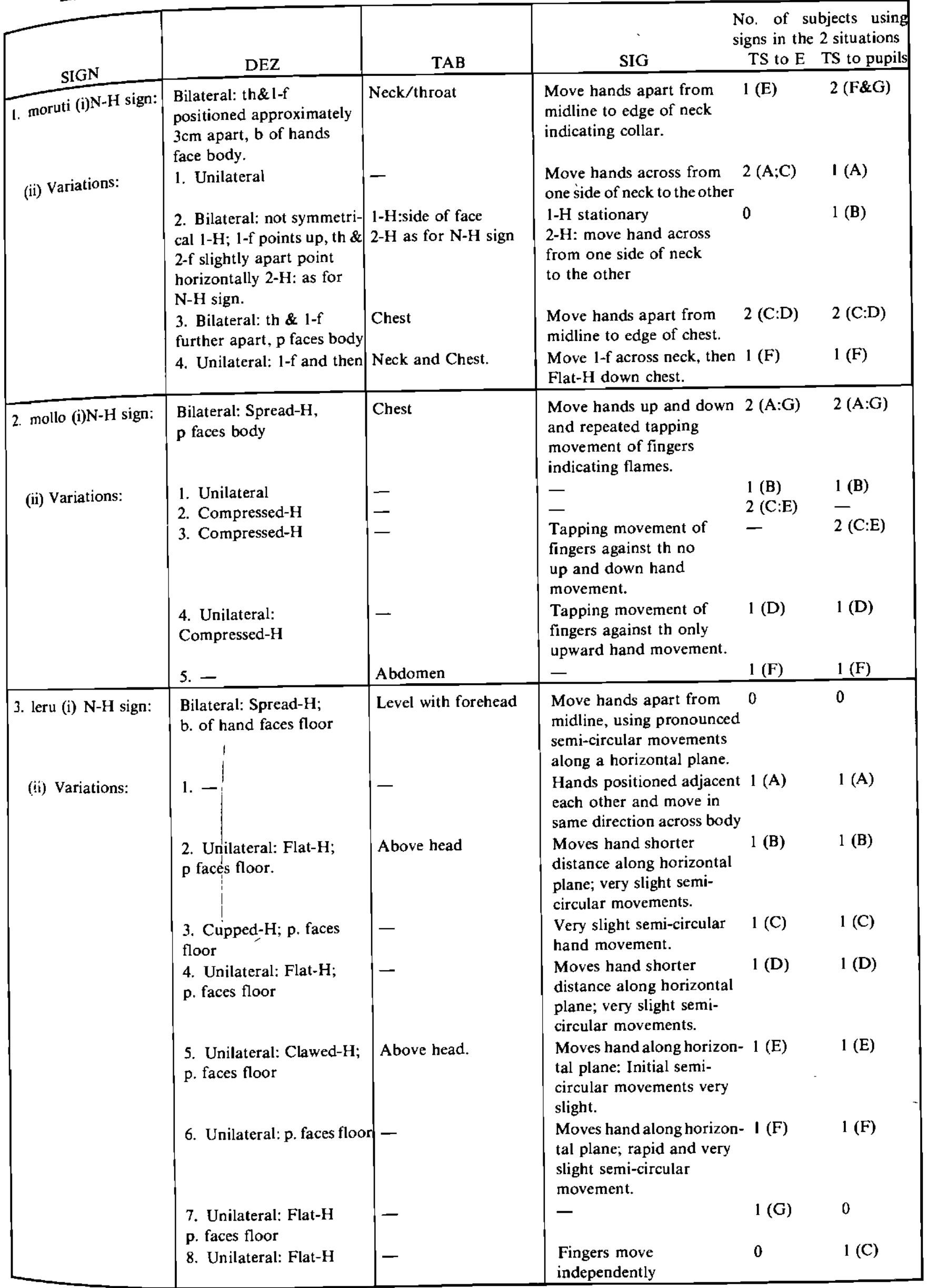




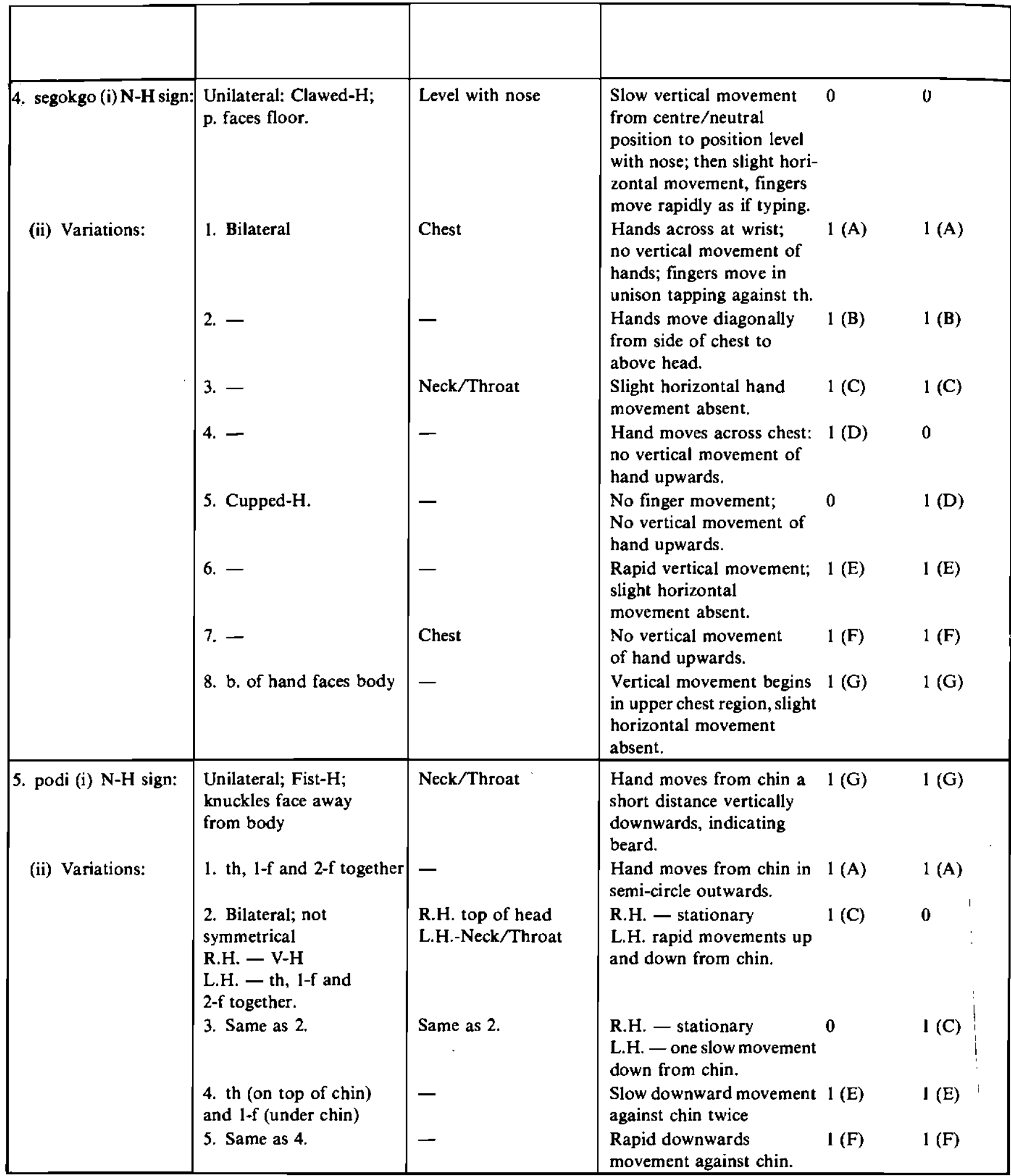

KEY:

f - finger

p - palm

- 3-f - third finger

R.H. - right hand

Spread-H - Spread-Hand

Clawed-H - Clawed-Hand

$\begin{array}{ll}\text { th - thumb } & \text { b - back } \\ \text { I-f - first finger } & 2-\mathrm{f}-\text { second finger } \\ \text { I-H - first hand } & 2-\mathrm{H}-\text { second hand } \\ \text { L.H. - left hand } & \text { Flat-H - Flat-Hand } \\ \text { Compressed-H - Compressed Hand Cupped-H - Cupped-Hand } \\ \text { Fist-H - Fist-Hand } & \text { V-H }- \text { V-Hand }\end{array}$


Table 2 Signed nouns used by each Teacher Subject in terms of whether they are Nieder-Heit mann Signs, variations thereof, or totally different from the Nieder-Heitmann sign, and number and percentage of occurrence within each category in both situations across all nouns.

\begin{tabular}{|c|c|c|c|c|c|c|c|c|c|c|c|c|}
\hline \multirow[b]{2}{*}{ TSs } & \multirow{2}{*}{$\begin{array}{l}\text { Situ- } \\
\text { ation }\end{array}$} & \multirow[b]{2}{*}{ moruti } & \multirow[b]{2}{*}{ mollo } & \multicolumn{3}{|c|}{ SIGN } & \multicolumn{2}{|c|}{$\mathrm{N}-\mathrm{H}$} & \multicolumn{2}{|c|}{$\mathrm{V}$} & \multicolumn{2}{|c|}{$\mathrm{D}$} \\
\hline & & & & leru & segokgo & podi & $\mathrm{No} / 10$ & $\%$ & $\mathrm{No} / 10$ & $\%$ & $\mathrm{No} / 10$ & $\%$ \\
\hline $\mathrm{A}$ & $\begin{array}{l}- \\
+ \\
\end{array}$ & $\begin{array}{l}\mathrm{v} \\
\mathrm{v} \\
\end{array}$ & $\begin{array}{l}\mathrm{N}-\mathrm{H} \\
\mathrm{N}-\mathrm{H} \\
\end{array}$ & $\begin{array}{l}\mathrm{v} \\
\mathrm{v} \\
\end{array}$ & $\begin{array}{l}\mathrm{v} \\
\mathrm{V} \\
\end{array}$ & $\begin{array}{l}\mathrm{V} \\
\mathrm{V} \\
\end{array}$ & 2 & 20 & 8 & 80 & - & - \\
\hline B & $\begin{array}{l}- \\
+ \\
\end{array}$ & $\begin{array}{r}D \\
-\quad v \\
\end{array}$ & $\begin{array}{l}\mathrm{v} \\
\mathrm{v} \\
\end{array}$ & $\begin{array}{l}\mathrm{V} \\
\mathrm{V}\end{array}$ & $\begin{array}{l}\mathrm{v} \\
\mathrm{v} \\
\end{array}$ & $\begin{array}{l}\mathrm{D} \\
\mathrm{D}\end{array}$ & - & - & 7 & 70 & 3 & 30 \\
\hline $\mathrm{C}$ & $\begin{array}{l}- \\
+\end{array}$ & $\begin{array}{l}\mathrm{v} \\
\mathrm{v}\end{array}$ & $\begin{array}{l}\mathrm{v} \\
\mathrm{v}\end{array}$ & $\begin{array}{l}\mathrm{V} \\
\mathrm{V}\end{array}$ & $\begin{array}{l}\mathrm{V} \\
\mathrm{V}\end{array}$ & $\begin{array}{l}\mathrm{v} \\
\mathrm{v}\end{array}$ & - & - & 10 & 100 & - & - \\
\hline D & $\begin{array}{l}- \\
+ \\
\end{array}$ & $\begin{array}{l}\mathrm{v} \\
\mathrm{v}\end{array}$ & $\begin{array}{l}\mathrm{v} \\
\mathrm{V} \\
\end{array}$ & $\begin{array}{l}\mathrm{v} \\
\mathrm{v}\end{array}$ & $\begin{array}{l}\mathrm{V} \\
\mathrm{V}\end{array}$ & $\begin{array}{l}\mathrm{D} \\
\mathrm{D}\end{array}$ & - & - & 8 & 80 & 2 & 20 \\
\hline $\mathrm{E}$ & $\begin{array}{l}- \\
+ \\
\end{array}$ & $\begin{array}{l}\mathrm{N}-\mathrm{H} \\
\mathrm{N}-\mathrm{H} \\
\end{array}$ & $\begin{array}{l}\mathrm{v} \\
\mathrm{v} \\
\end{array}$ & $\begin{array}{l}\mathrm{v} \\
\mathrm{v} \\
\end{array}$ & $\begin{array}{l}\mathrm{V} \\
\mathrm{V} \\
\end{array}$ & $\begin{array}{l}\mathrm{v} \\
\mathrm{v} \\
\end{array}$ & 2 & 20 & 8 & 80 & - & - \\
\hline F & $\begin{array}{l}- \\
+\end{array}$ & $\begin{array}{l}\mathrm{V} \\
\mathrm{V}\end{array}$ & $\begin{array}{l}\mathrm{v} \\
\mathrm{v}\end{array}$ & $\begin{array}{l}\mathrm{V} \\
\mathrm{V}\end{array}$ & $\begin{array}{l}\mathrm{V} \\
\mathrm{V}\end{array}$ & $\begin{array}{l}\mathrm{V} \\
\mathrm{v}\end{array}$ & - & - & 10 & 100 & - & - \\
\hline & $\begin{array}{l}- \\
+ \\
\end{array}$ & $\begin{array}{c}\mathrm{V} \\
\mathrm{N}-\mathrm{H} \\
\end{array}$ & $\begin{array}{l}\mathrm{N}-\mathrm{H} \\
\mathrm{N}-\mathrm{H} \\
\end{array}$ & $\begin{array}{l}\mathrm{V} \\
\mathrm{v}\end{array}$ & $\begin{array}{l}\mathrm{V} \\
\mathrm{V} \\
\end{array}$ & $\begin{array}{l}\mathrm{N}-\mathrm{H} \\
\mathrm{N}-\mathrm{H} \\
\end{array}$ & 5 & 50 & 5 & 50 & - & - \\
\hline $\mathbf{x}$ & & & & & & & 9 & 13 & 56 & 80 & 5 & 7 \\
\hline
\end{tabular}

Table 3 Description of Paget-Gorman Signs within DEZ, TAB and SIG formations (Nieder-Heitmann 1980)

\begin{tabular}{|l|l|l|l|}
\hline SIGN & DEZ & TAB & SIG \\
\hline $\begin{array}{l}\text { teacher (moruti) } \\
\text { (no sign for preach/er) }\end{array}$ & $\begin{array}{l}\text { 1-H: 1-f pt up, tl \& 2nd finger pt } \\
\text { horizontally. 2-H: compressed } \\
\text { hand }\end{array}$ & $\begin{array}{l}\text { 1-H level with shoulder } \\
\text { 2-H-side forehead }\end{array}$ & $\begin{array}{l}\text { 1-H: extend tl \& 1 finger } \\
\text { outwards. 2-H-Twist wrist to } \\
\text { open hand }\end{array}$ \\
\hline fire: (mollo) & $\begin{array}{l}\text { (Unilateral) 5 point-hand. } \\
\text { (fingers \& thumb pt upward- } \\
\text { straight \& seperate from one } \\
\text { another) }\end{array}$ & Side of chest & $\begin{array}{l}\text { Move all digits simultaneously } \\
\text { \& independently of one another }\end{array}$ \\
\hline cloud (leru) & $\begin{array}{l}\text { Unilateral, spread-hand, } \\
\text { palm faces floor }\end{array}$ & Forehead & Vibrate hand vertically \\
\hline segohgo (spider) & $\begin{array}{l}\text { Unilateral clawed hand } \\
\text { p. faces floor }\end{array}$ & Shoulder & $\begin{array}{l}\text { Hand lowers vertically, one } \\
\text { hand length moving digits } \\
\text { independantly }\end{array}$ \\
\hline podi (goat) & $\begin{array}{l}\text { 1-H; 1-f \& 4-f up; 2-f \& 3-f on } \\
\text { th. palm faces floor. } \\
\text { 2-H: 1-f on side 4-f. 1-H \& th } \\
\text { on side 2-f 1-H }\end{array}$ & 1-H: shoulder & $\begin{array}{l}\text { 2-H: lower 1/2h. breadth } \\
\text { closing Th \& 1-f. }\end{array}$ \\
\hline
\end{tabular}


Table 4 Description of the Nieder-Heitmann object pronoun sign across the cheremic configurations, and variations thereof

\begin{tabular}{|l|l|l|l|}
\hline SIGN & DEZ & TAB & SIG \\
\hline N-H sign: & $\begin{array}{l}\text { Unilateral; 1-f points diagonally } \\
\text { downwards. }\end{array}$ & $\begin{array}{l}\text { Side of body (same side as : } \\
\text { hand involved) }\end{array}$ & Stationary \\
\hline Variations: & $\begin{array}{l}\text { Dez 1: Bilateral } \\
\text { Dez 2: f points straight or } \\
\text { diagonally upwards. }\end{array}$ & $\begin{array}{l}\text { Tab 1: f points to front of body. } \\
\text { Tab 2: f points above head. }\end{array}$ & $\begin{array}{l}\text { Sig 1: hand moves across body } \\
\text { Sig. } 2: ? ? ?\end{array}$ \\
\hline
\end{tabular}

Table 5 Description of the Nieder-Heitmann plural sign across the cheremic configurations, and variations thereof

\begin{tabular}{|l|l|l|l|}
\hline SIGN & DEZ & TAB & SIG \\
\hline N-H sign: & Unilateral: th and 1-f meet. & $\begin{array}{l}\text { Side of chest below shoulder of } \\
\text { opposite side. }\end{array}$ & $\begin{array}{l}\text { Move hand across chest from } \\
\text { shoulder on same side to lower } \\
\text { position below shoulder of } \\
\text { opposite side. }\end{array}$ \\
\hline Variations: & - & $\begin{array}{l}\text { TAB 1: mid-chest area. } \\
\text { TAB 2: lower face/neck area. } \\
\text { TAB 3: side of body opposite } \\
\text { face. } \\
\text { TAB 4: mouth } \\
\text { TAB 5: shoulder of same side. }\end{array}$ & $\begin{array}{l}\text { SIG 1: no movement of hand } \\
\text { from shoulder of same side to other } \\
\text { shoulder. } \\
\text { SIG 2: hand moves from midline of } \\
\text { chest to opposite shoulder. } \\
\text { SIG 3: hand moves from shoulder } \\
\text { to midline of chest. }\end{array}$ \\
\hline
\end{tabular}

were taught to the pupils, but believed the teachers used the written mode. A single TS stated that she finger-spelled the prefixes and another emphasized the role of lip-reading. Five TS's stated that no instruction had been given to them on how to convey noun classes. (The remaining two TS's appeared to miscomprehend the question, and responded inappropriately).

III The object pronoun and plural forms

As indicated above the noun prefixes for both structures were not distinguished through manual means. They were illustrated purely as lexical items by their respective $\mathrm{N}-\mathrm{H}$ signs or variations thereof, as were the singular nouns.

The most interesting variations occurred for the object pronoun. The N-H sign does not account for a location shift, according to the direction in space appropriate to the person or object being referred to. However, in the variations used by some TS's (see Table 4) it appears that there was an attempt to increase the morphological information. This is in accordance with pronominalisation in American Sign Language as well as various MCE systems (Gustason 1980). The N-H sign employs the non-manual component of eye direction - the signer is required to look at his hand when signing; presumably to indicate who is being referred to. This was observed in only two of the TS's.

The $\mathrm{N}-\mathrm{H}$ plural sign and variations thereof are described in Table 5 . It can be seen that there was a great deal of variation in both the TAB and the SIG cheremes. Signs changed position in front of the body, in close conjunction with the context sign (Schlesinger, 1978), and this principle was clearly seen operating here. A general trend was that the formation of the plural marker was less discrete in syntactic context than in isolation.

IV Results of the questionnaire put to Teacher Subjects

1) A single TS had a Diploma in Special Education - the others had only a General Primary Teacher's Diploma. Evans (1982) feels that professional education of teachers of the deaf should provide for instruction in manual communication during a specialised period of study.
2) The period of service at the school ranged from 6 to 12 years. This suggests that all the TS's had been exposed to a signing system which differed from $\mathrm{N}-\mathrm{H}$ for several years prior to its introduction. It would thus be expected that some confusion with the "old" system would arise, particularly if it is used by the children as their natural sign system.

3) The TS's stated they had been taught "the signs" by the more exerienced teachers at the school, as well as from the pupils and by using the text Talking to the Deaf (Nieder-Heitmann 1980). It appears that in-service training is the present mode of teacher instruction.

All the TS's and the school principal acknowledge the variability in the signs used and cite the following reasons:

(a) the recent change in the sign system

(b) the fact that natural sign is still used by the older pupils who "do not understand the new signs"

(c) the N-H system is in its "first phase" of development an'd is limited.

\section{DISCUSSION}

This study serves to illustrate the difficulty experienced by hearing educators, in learning a prescribed manual code. The results obtained are further confirmed by Du Plessis (1985) who observed similar variation in the signing of the $\mathrm{N}-\mathrm{H}$ code by teachers in several schools for the black deaf. The explanations given to him by the teachers as to why their signing was inaccurate, are similar to those given by the TS's in this study. His subjects believed that:-

The manual (Talking to the Deaf) was obsolete, the varied groups using signs in the Republic were not consulted when it was compiled, and that the signs are probably based on those used by whites. The children are confused by the introduction of 'new' signs, and it is not a bona fide sign language and is unfit to use for communication.

As a manual code, designed to teach the syntax of spoken Tswana, the N-H code appears to have few attributes of the more popular codes, namely:- to supplement already existing signs and to increase the input to the child of vocabulary and morphological markers, as well as other structural elements (Gustason, 1980). 
There is universal support for initial mother-tongue education (UNESCO 1953, cited by Reagan, 1986), so that many educators of the deaf are advocating the use of natural sign language as the medium of instruction in schools. In the multicultural, multilingual and multiethnic population of South Africa it is postulated that there would be much linguistic diversity in Deaf communities. Little research has been carried out on the lexical, syntactic and cheremic nature of these languages (Lewis, 1984; Reagan, 1986; Morgan, 1986).

Languages originate when people come together to form a society. The entire socio-cultural context of language users must be considered (Erting 1981; Stokoe 1979). As in the United States, South African languages probably also underwent development. American Sign Language (ASL) was "creolised" from imported French signs, the indigenous signs of America and the sign languages which developed on school campuses where deaf children intermingled. The language was restructured on lexical, syntactic and cheremic levels and became more arbitrary (Woodward, 1978, cited by Morgan, 1986). This phenomenon probably occurred in South Africa, which might explain the transition from the P-G code, to the present varied signs used. This creative construction of sign languages meets the communicative needs of its users, as with spoken languages.

Several educators in South Africa may find virtue in the similarities between the apparent varied number of sign languages used in South Africa and even ASL and Gestuno to meet their principal needs (Viljoen, 1982) but this is spurned by the deaf (Jones, 1982), and they violate current research findings (Battison \& Jordan, 1980).

If Manual Codes are devised by educators to teach spoken language, it seems logical that they should resemble the natural language as closely as possible. Quigley and Paul (1984) differentiate between Manual Code in their natural form and those that are artificially invented. In its natural form, a Manual Code uses the lexicon of the natural sign language of each deaf community and does not artificially invent signs for words or counter-act the existing signs. Empirical research is likely to reveal varied lexicons for deaf groups in South Africa (Penn et al., 1984).

\section{CONCLUSION}

No signs for encoding the morphological structures of Tswana were evident in this study. Although most of the TS's in this study showed awareness of having to convey the noun class system in the classroom, a manual form for such instruction is not used. The efficacy of encoding the syntax of a spoken language, in order to aid the deaf child to acquire competence, is yet to be proved (Quigley \& Paul 1984). Some studies have shown that deaf children have similar receptive competence of inflectional markers to their hearing peers, when the markers are manually encoded. These children are suprerior to those using oralism only (Bornstein et al., 1978). However, writers such as Cokeley and Baker (1980) question the advisability of supplying too many sensory stimuli simultaneously. They also state that few hearing individuals (teachers) may be sufficiently competent to sign all the spoken elements of language while speaking. The possible limitations of attempting to faithfully represent the structure of a highly inflected language such as Tswana should be borme in mind.

Further research into the advisability of devising a manual code to teach the noun class prefixes of Black language is required. Wilbur (1976: 451) states

... no matter what the drawbacks are of any of these systems...

there is strong.evidence that manual communication in any form is itself a more effective teaching medium than a straight oral approach.

The writers express their concern at the dearth of empirical research into South African signing systems. The Department of Education and Training has pioneered the use of Total Communication for teaching language to deaf black children. However, for this method to be truly effective, the most appropriate sign system should be selected. This can only be done with reference to the vast body of literature on signing and by studying current trends overseas. Psycholinguists, with a background of knowledge in manual communication, should together with other related workers, research in the rich heritage of deaf culture and sign language in this country.

\section{REFERENCES}

Battison, R; Jordan and King, I. Cross Cultural Communication with Foreign Signers. Fact and Fancy. Sign Language Studies, $10,53-68,1980$.

Bornstein, H. Sign Language in Education of the Deaf. Sign Language of the Deaf. Psychological, Linguistic and Sociological Perspectives, Schlesinger, I.M. and Namier, L. (eds). Academic Press, Inc., New York, 1978.

Cokeley, D. and Baker, C. American Sign Language: A Teacher's Resource text on Grammar and Culture TJ Publishers Inc., Maryland, 1980.

Cole, D.T. An Introduction to Tswana Grammar. (4th Impression) Longman Penguin Southern Africa, Cape Town, 1982.

Crystal, D., Fletcher, P. and Garman, M. The Grammatical Analysis of Language Disability. A procedure for assessment and remediation. Edward Arnold Ltd., London, 1976.

Du Plessis, J.C.L. Report on Black Education: Sign Languages. In Biennial Council Meeting Reports. SA National Council for the Deaf, October 24-25, 1985.

Erting, C. An Anthropological Approach to the Study of Communicative Competence of Deaf Children. Linstok Press, Maryland, 1981.

Evans, L. Total Communication. Structure and Strategy. Gallaudet College Press, Washington D.C., 1982.

Gustason, G. and Rosen, R. Effective Sign Communication for Instructional Purposes. In Using Signing Exact English in Total Communication. Gustason, G. and Zawolkow, E (eds) Modern Signs Press, 1980.

Gustason, G. Manual English and American Sign Languages: Where do we go from here? In Language in Sign: An International Perspective on Sign Language. Kyle, J.G. and Woll, B. (eds). Croom Helm., Kent, 1982.

Jones, A. Letter addressed to the National Council for the Deaf on behalf of the Adult Deaf Association, Durban, Natal, 1982.

Klima, E. and Bellugi, U. The Signs of the Language, Harvard University Press, Massachusetts, 1980.

Lewis, R.E. An Overview of the Research into the American Sign Language Continuum and its relevance to South African Sign Languages and Codes. In Proceedings of the Conference of the Linguistic Society of South Africa. Pretoria, July, 356-403, 1984

Liddell, S.K. American Sign Language System. Monton, 1980.

Morgan, R.Z. Sign Language in South African Black Communities - Implications for Future Research. Unpublished dissertation submitted to the Department of Linguistics, Faculty of Arts, University of the Witwatersrand, Johannesburg, 1986.

Nieder-Heitmann, N. Talking to the Deaf, Government Press, Pretoria, 1980.

Penn, C., Lewis, R. and Greenstein, A. Sign Language in South Africa: Some Research and Practical Issues. The South African Journal of Communication Disorders, 31, 6-11, 1984.

Quigley, S.P. and Paul, P.V. Language and Deafness, College-Hall Press, Inc., San Diego, California, 1984. 
Reagan, T.G. Sign Language Diversity in South Africa: A Preliminary Investigation, with Implications for the Education of the Deaf. Unpublished proposal for a Research Project, 1986.

Schlesinger, H.S. The Acquisition of Signed and Spoken Language. In Deaf Children: Developmental Perspectives. Liben, L.S. (Ed). Academic Press, Inc., New York, 1978.

Stokoe, W.C. The Study and Use of Sign Language. Sign Language Studies. 10, 1-36, 1976.

Stokoe, W.C. Sign and Culture, Linstok Press, Maryland, 1978. Stokoe, W.C. and Kuschel, R.A. A Field Guide for Sign Language
Van der Merwe, A.J. Deputy Director - Special Education, Department of Education and Training, Pretoria, Personal Communication, March, 1986.

Viljoen, S.W. Communication Skills Project - Editorial, Silent Messenger, South African National Council for the Deaf, V 5, No 3, July/August, 1982.

Wilbur, R.B. The Linguistics of Manual Language and Manual Systems. In Communication Assessment and Intervention Strategies. Lloyd, L.L. (ed). University Park Press, Baltimore, 1976. 